\title{
DEVELOPING NON-COGNITIVE SKILLS IN PART-TIME STUDENTS AT A SOUTH AFRICAN UNIVERSITY: OVERCOMING NEGATIVITY AND SUPPORTING BEHAVIOURAL CHANGE
}

\author{
A. Merino* \\ e-mail: andres.merino@wits.ac.za
}

\section{S. Jooste*}

e-mail: sandra.jooste@wits.ac.za

\section{K. Vermeulen*}

e-mail: katinka.vermeulen@wits.ac.za

*Management Accounting and Finance Division

School of Accountancy

University of the Witwatersrand

Johannesburg, South Africa

\section{ABSTRACT}

This article reports on the findings of an intervention aimed at assisting a group of thirty-one parttime students registered for a third year Management Accounting and Finance course to develop a range of non-cognitive skills that have been shown to positively impact academic behaviour. In addition to facilitating the teaching and learning of academic content, lecturers introduced students to academic mindsets, academic behaviours, learning strategies and social skills through roleplays and practical demonstrations. The intervention also strove to influence the context in which students learned in order to positively influence the attitudes of the students towards the course and to motivate them to acquire and practice behaviours that would support their learning. The intervention involved two action research cycles in which the researchers were able to reflect on the effectiveness of the various approaches used to encourage behaviour change and the acquisition of new skills. The findings of the study indicate that the intervention was successful in developing a range of non-cognitive attitudes, strategies and behaviours in students, with most of the cohort reporting positive changes in attitude towards their studies and the belief that academic success was indeed possible.

Keywords: academic mindsets; academic behaviours; learning strategies; social skills; academic perseverance; non-cognitive skills; part-time students; accounting education

\section{INTRODUCTION}

Prior research has established that students who are able to display a range of non-cognitive 
skills tend to perform well academically (Zimmerman 2002; Pintrich 2004; Silén and Uhlin 2008; Nagaoka et al. 2013; Dweck 2017). Amongst these skills, the role of having an academic mindset has been particularly highlighted as being an important catalyst for academic success. An academic mindset comprises the psycho-social beliefs or attitudes that one has about oneself in relation to academic work (Aronson, Cohen and McColskey 2009; Dweck, Walton and Cohen 2011; Farrington et al. 2012). Students who display an academic mindset adopt social skills that allow them to seek assistance, are more likely to persevere in the attainment of their goals and to put effort into developing effective learning strategies. These non-cognitive skills all translate into academic behaviours that make academic success more likely (Blackwell, Trzesniewski and Dweck 2007; Yeager and Walton 2011).

Both cognitive and non-cognitive success factors are seldom made explicit to students by lecturers as lecturers tend to assume that if students have qualified to access tertiary institutions they must already have acquired the necessary skills and attributes to cope with the requisite academic demands (Tishman and Jay 1993). The other challenge that many lecturers face; especially in degrees that lead to professional qualifications - as is the case with accountancy - is that lecturers usually have little training in pedagogy (Wilmot and Merino 2015). By default they lecture in the same way that they were lectured without taking into account the fact that the South African student population has undergone a great deal of change and that many students enrolling for tertiary degrees may lack the necessary non-cognitive skills needed to succeed (Cross and Carpentier 2009; Pym and Kapp 2013).

This article describes the process that was followed by two lecturers to design and implement an intervention to equip part-time students studying a third year course in Management Accounting and Finance with a range of non-cognitive skills that would support them in their pursuit of academic success. Traditionally the pass rate of part-time students in this course has been low, resulting in many students having to do the course two or three times before passing it. As a result of this many of the repeating students have developed a negative attitude towards the course and have been quite forthright in expressing their concerns through course evaluation forms. The lecturers therefore set out to challenge and redirect the negative attitudinal and behavioural patterns exhibited by the students by introducing them to a range of non-cognitive skills and by trying to positively influence the learning environment in which they learned.

The research component of this intervention was conducted by the two lecturers themselves. The two lecturers had taught the full time course for many years. Important to note is the fact that both lectures were going to teach the part-time equivalent of the course for the first time. The research process was structured around two action research cycles. The first 
cycle introduced students to the principle of academic mindsets and to an extensive range of non-cognitive skills. The second cycle was designed once the data from the first cycle had been collected and analysed. In the following sections the two lecturers/researchers explain the conceptual framework that guided the design of the intervention and the activities that were carried out with the students in the first action research cycle. This is then followed by an analysis of the feedback that was received from the students as well as an analysis of the two lecturers' reflections on the challenges that they encountered. The second action research cycle is then introduced and the data collected in this cycle is analysed. The article concludes with reflections on how the intervention shaped the academic journeys of the students involved and on the insights gained by the lectures with regard to what is needed to overcome negative attitudes and to achieve behavioural change.

\section{CONCEPTUAL FRAMEWORK UNDERPINNING THE RESEARCH}

Non-cognitive skills refer to the range of attitudes, behaviours and strategies that students need to possess in order to do well academically (Zimmerman and Risemberg 1997; Dembo and Seli 2013). Research has shown that an effective way to influence the acquisition of these skills is by creating learning environments or "contexts" that support students holistically (Cooper, Robinson and Patall 2006). In these contexts lecturers do not only introduce students to effective ways of acquiring content knowledge, but they also help students to develop the academic behaviours and the social skills that they need in order to succeed (Bandura 2011).

An extensive amount of research has focussed on identifying the impact on students' performance of non-cognitive skills such as time management, help seeking behaviours, metacognition strategies, problem solving skills, self-control and persistence (Karabenick and Dembo 2011; Steenkamp, Baard and Frick 2012). There is also an area of research that has looked at the psycho-social beliefs of students in terms of their beliefs about intelligence, selfefficacy, social belonging and the setting of goals as determinants of student success (Bandura 1986; Zimmerman, Bandura and Martinez-Pons 1992).

In an effort to bring together the existing literature on non-cognitive skills Farrington et al. (2012) developed a conceptual framework that is made up of five general factors that that are related to academic performance. The factors that have been identified are: academic mindsets, social skills, academic perseverance, learning strategies and academic behaviours. Figure 1 shows the conceptual framework and how the various non-cognitive factors combine to affect academic behaviour. The novelty of this framework is that it highlights how the various factors interact with each other. This is useful as it provides practitioners with a richer understanding of how particular interventions could be structured in order to support students 
in their efforts to acquire new skills. The interactions between these factors and how they influence academic performance are explained in the following sections.

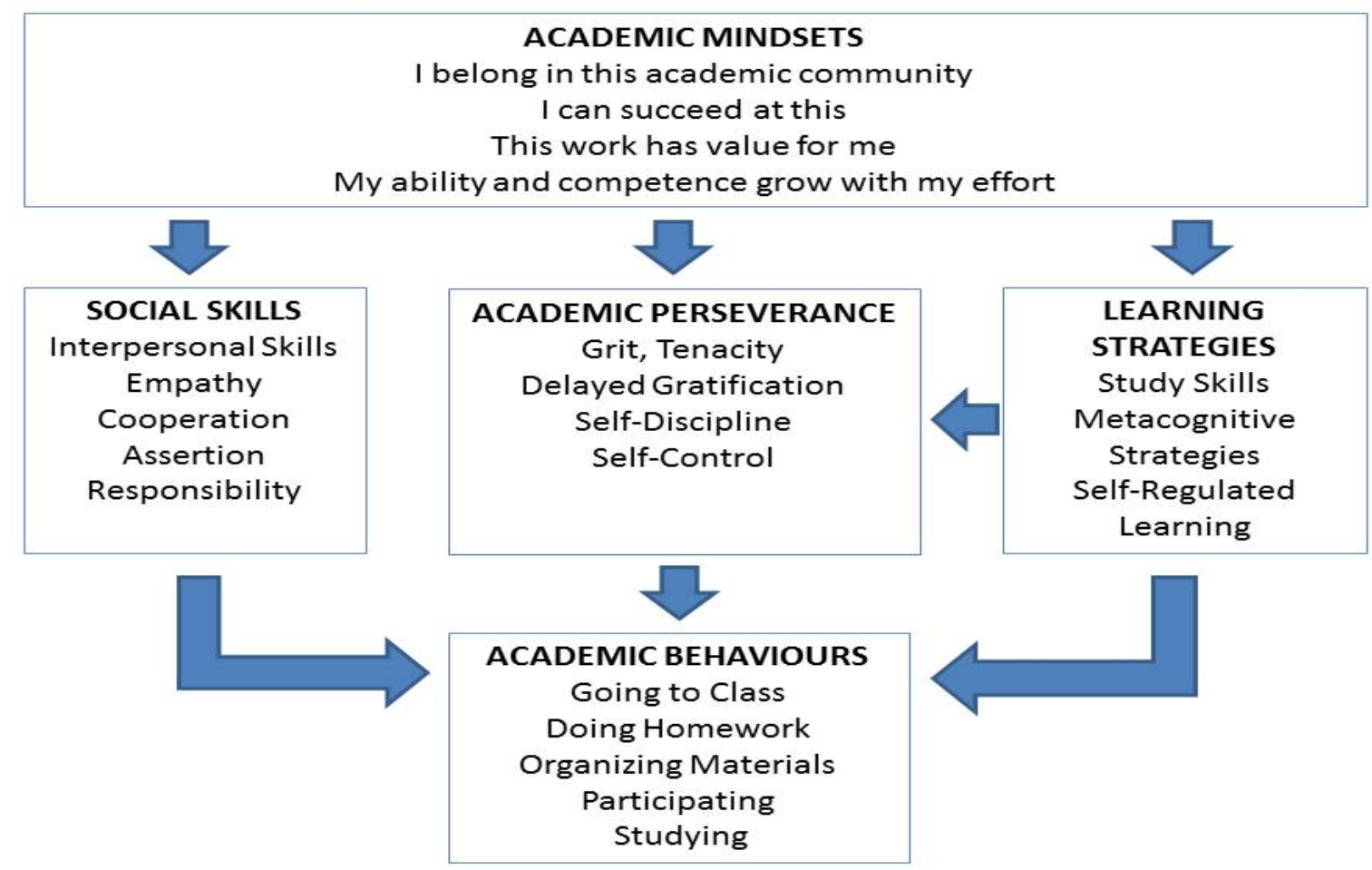

Figure 1. Non-Cognitive Skills Five Factor Model

\section{Academic mindsets}

Within the model, four aspects of Academic Mindsets are identified. The first one is that students need to feel that they belong to the academic community in which they are learning. There is a long line of research that links having a sense of belonging with academic success (Harvey and Schroder 1963; Goodenow 1993; Oyserman, Bybee and Terry 2006; Cohen and Garcia 2008; Won, Wolters and Mueller 2017). In the case of part-time students this is particularly important as they sometimes struggle with not having a sense of belonging (Kember 1999; Kasworm 2008). Students also need to believe that they can succeed in their studies, and that there is a direct link between their efforts and academic results (Zimmerman 2008; Dweck 2017). The link between effort and results is challenged when students start to experience difficulties in their studies. It is therefore important for lecturers to be able to properly channel the attitudes of failing students so that they react positively to the academic challenges that they may be facing (Bandura 1986). Students also need to be conscious of the value of their studies as there is a clear link between students' perceived value of the work that they are doing and motivation and class attendance (Eccles et al. 1983; Pintrich and De Groot 1990; Allensworth and Easton 2007). 


\section{Social skills}

Social skills include interpersonal qualities such as co-operation, assertion, responsibility and empathy where learning is understood as a social activity in which knowledge is constructed through interactions with others (Dewey 1958; Vygotsky 1978; Durlak et al. 2011). This factor also includes social interactions between peers and between students and lecturers. Social skills are particularly important in collaborative learning environments in which students need to interact in order to learn (Vygotsky 1978; Bandura 1997; Malecki and Elliot 2002).

\section{Academic perseverance}

Academic perseverance refers to students' ability to stay focused on their studies (Duckworth and Seligman 2005; Hlalele 2010). It entails having the grit to persistently push forward towards a particular goal despite disappointments, distractions or challenges faced throughout the course (Duckworth and Seligman 2005; Urban and Richard 2015). Furthermore, academic perseverance includes delayed gratification, self-discipline and self-control all of which have been positively associated with the academic behaviours of successful students (Dembo and Seli 2013).

\section{Learning strategies}

Learning strategies encompass the capacity of students to perform study tasks such as critical reading, analysing and making summaries, as well as their ability to reflect on the effectiveness of their study approach (Farrington et al. 2012). Metacognitive strategies allow students to stand back and reflect on how they think and learn. There is a wide variety of learning styles and approaches, and what may work for one student may not necessarily work for another. Learning strategies are also influenced by a students' specific personality traits (Bidjerano and Yun Dai 2007). Students require insight into and awareness of their preferred learning styles and personality drivers for them to be able to adapt and change their approach in order to meet new study goals. This adjustment is achieved through self-regulated learning strategies (Paris and Winograd 1990; Zimmerman 2002; Radovon 2011; Merino, Jooste and Vermeulen 2017). Before starting a task students who self-regulate, set themselves study goals and determine strategies on how they are going to achieve those goals. During their study time they stay focussed and carry out the study tasks as planned, and upon completion of their study time they reflect on the effectiveness of their study approach and determine whether or not their study approach needs to be modified (Paris and Winograd 1990; Radovon 2011). 


\section{Academic behaviours}

Academic behaviours refer to the behaviours that are expected of successful students; these include: attending lectures, doing homework, organising course materials and participating in class discussions and activities. Students not only develop their content knowledge through these behaviours, but also demonstrate that they are engaging with course material (Nagaoka et al. 2013). Schreiber and Yu (2016) found a significant and positive relationship between student engagement and academic performance.

As can be seen in Figure 1 Academic Behaviours related to good academic outcomes are the result of the interaction of Academic Mindsets, Social Skills, Academic Perseverance and Learning Strategies. Knowing about the factors and how they interact provides a solid foundation on which to build interventions, however the challenge for lecturers and practitioners remains to be able to devise effective interventions that are successful in addressing the needs of particular groups of students (Gynnild, Holstad and Myrhaug 2008).

\section{DESCRIPTION OF THE INTERVENTION}

The intervention took place in first semester of 2016. The thirty one students who participated in the study were part-time Management Accounting and Finance III students. Out of the thirty one students twenty four of them were repeat students ( $77 \%$ of the total class). Of the twenty four repeat students, fifteen were repeating the course for the first time. Five had failed the course twice, three were repeating for the third time and one was repeating for the fourth time. Management Accounting and Finance is a demanding course as it requires high levels of analytical and problem-solving skills. In addition it is demanding in terms of the amount of content needed to be mastered given the available lecture time. In total there were twelve contact sessions offered in the semester and each session was limited to three hours. The lectures took place on Tuesdays starting at $5.30 \mathrm{pm}$. Prior to the commencement of the intervention, ethical clearance was sought and granted by the University's Human Research Ethics Committee.

\section{Action research}

Action research is cyclical in nature and involves identifying a problem, such as an issue related to student learning; designing and implementing an action plan; collecting data stemming from the action taken; reflecting on the plan and the data obtained; and then updating or modifying the plan so that a further research cycle can be started (Cunningham 2008; McNiff and Whitehead 2009). This intervention included two action research cycles. The first action research cycle consisted of six consecutive weeks of lectures. The lectures were structured to 
cover the syllabus of the course and to introduce students to the various aspects of the NonCognitive Skills Five Factor Model. In each session a particular strategy or skill was introduced by one of the lecturers while the other lecturer observed the class and made notes on how students reacted to the material presented to them. Table 1 contains the plan of action that was prepared to address key skills and strategies throughout the first teaching cycle. The second teaching cycle also involved six weeks of lectures. The structure of the second teaching cycle was only determined after analysing the data and the feedback collected from the first teaching cycle. Areas of the Non-Cognitive Skills Five Factor Model were subsequently reinforced during the second teaching cycle.

Table 1: First teaching cycle

\begin{tabular}{|c|l|l|l|}
\hline Week & \multicolumn{1}{|c|}{ Lecture topic } & \multicolumn{1}{|c|}{ Skills addressed } & \multicolumn{1}{c|}{ Implementation plan } \\
\hline 1 & $\begin{array}{l}\text { Revision of } \\
\text { second year } \\
\text { material }\end{array}$ & $\begin{array}{l}\text { Academic Mindsets } \\
\text { I belong in this academic } \\
\text { community and I can succeed } \\
\text { at this }\end{array}$ & $\begin{array}{l}\text { Build trust by showing empathy and by } \\
\text { discussing challenges unique to part-time } \\
\text { students. } \\
\text { Explain the role of non-cognitive factors in } \\
\text { academic success. }\end{array}$ \\
\hline 2 & $\begin{array}{l}\text { Cost } \\
\text { Classifications }\end{array}$ & $\begin{array}{l}\text { Learning Strategies } \\
\text { Relating theory to practice } \\
\text { and preferred learning styles }\end{array}$ & $\begin{array}{l}\text { Read relevant sections of the textbook with } \\
\text { students; apply the principles in the textbook } \\
\text { to a scenario. } \\
\text { Introduce students to learning styles and } \\
\text { guide them to determine their preferred } \\
\text { learning style. }\end{array}$ \\
\hline 3 & $\begin{array}{l}\text { Inventory } \\
\text { valuation }\end{array}$ & $\begin{array}{l}\text { Learning Strategies } \\
\text { Time management and } \\
\text { Preparing summaries } \\
\text { and encourage students to do weekly } \\
\text { summaries and plan study time for the rest of } \\
\text { the term. }\end{array}$ \\
\hline 4 & Process costing & $\begin{array}{l}\text { Academic Perseverance } \\
\text { Grit and self-discipline }\end{array}$ & $\begin{array}{l}\text { Introduce students to Self-Regulation } \\
\text { (planning, implementation and review) } \\
\text { highlighting the role of motivation and self- } \\
\text { discipline. }\end{array}$ \\
\hline 5 & Standard costing & $\begin{array}{l}\text { Analyse a tutorial question individually first } \\
\text { and then in groups of four. Encourage } \\
\text { students to listen to others and put across } \\
\text { their ideas in a structured way. }\end{array}$ \\
\hline 6 & $\begin{array}{l}\text { Social Skills } \\
\text { participating in group } \\
\text { discussions }\end{array}$ & $\begin{array}{l}\text { Expose students to strategies to determine } \\
\text { what questions to answer first in a test as } \\
\text { well as coping strategies and stress } \\
\text { Exanagement techniques. }\end{array}$ \\
\hline
\end{tabular}

\section{METHODOLOGY}

A qualitative approach was used to explore the impact of the intervention on the development of the non-cognitive skills of the students (Menter et al. 2011). Data was collected from questionnaires and in the form of written and verbal feedback from group participants and from the lecturers' research diaries. Analysis of the data during the course of the intervention allowed for concurrent reinforcement. The following sources of data were used:

- Written feedback from students: Students were required to complete three questionnaires.

The initial questionnaire was given during the first session, the second after the first 
teaching cycle and course test, and the final at the end of the semester upon completion of the intervention. The aim of the first questionnaire was to gain greater understanding of the challenges faced by the students and to obtain insights into their academic goals and aspirations. The aim of the second questionnaire was to encourage students to reflect on the outcomes of the course test in order for them to ascertain where they went wrong and how they could change their approach going forward. The final questionnaire was administered to obtain student feedback on the intervention.

- Following the students' first course test upon completion of the first teaching cycle, a group feedback session was held which was recorded, transcribed and used to identify common themes through thematic content analysis (Fereday and Muir-Cochrane 2006).

- Lecture observations: during each session the lecturer that was not delivering the content observed and recorded how the sessions developed and made notes of the interactions between the lecturer and the students.

- Lecturers' self-reflection diaries: both lecturers involved in the intervention kept selfreflection diaries in which they recorded how each session unfolded. The dairies were also used to keep a record of the planning sessions that took place prior to each lecture.

\section{RESEARCHERS' EVALUATION OF THE FIRST TEACHING CYCLE}

Prior to the commencement of the course we obtained a large venue in which we could rearrange the furniture easily to facilitate group work and class discussions. When lectures were delivered the desks were arranged in a semi-circular shape so that all the students could easily see each other and the lecturer. We also provided each student with a folded name card that was displayed in front of them. This allowed us to get to know the students by name and also helped the students to get to know each other.

In the first lecture of the course we introduced students to the teaching philosophy that we were planning to use and presented to them our plan of action for the first six weeks of the course (see Table 1). The students were invited to be part of the study and we explained that some of the data was to be collected with questionnaires. It was made explicit that participation in the intervention was voluntary, that responses would be kept anonymous and that no one would be penalized for not participating. We then asked the students to complete the first questionnaire and to indicate whether they agreed to partake in the study. All the students agreed to take part in the study and signed consent forms.

The students were asked to indicate the challenges they anticipated in completing the module. Most of them mentioned lack of time to study, given their work and family 
commitments, as the main obstacle to do well in the course. Furthermore, the questionnaire asked the repeat students to list some possible reasons that could explain why they had failed before. The majority felt that the lecturers in the previous years were not competent enough to teach them properly, and had not provided enough academic support to help them to pass. The responses from the repeat students were not directed at a specific lecturer but were more indicative of the students' belief that the lecturers as a collective had not tailored the part-time program to address the specific challenges faced by part-time students.

In analysing these initial responses from the students it was clear that all the students were concerned about their prospects of passing the course. Some of the students new to the course were anxious given the poor pass rate on the course in the past, with many of the repeat students echoing the following comment from a student:

"I found the course difficult to pass and I have become scared of it. I attempted to pass so many times that I have almost given up on completing my degree."

The findings from the questionnaire were consistent with the views that were expressed by many of the students when we started to discuss the changes that we were proposing to make. For these students, part of the reason for failing was the fault of the previous lecturers. In reply to these concerns we explained that the new structure of the course had been designed precisely to take into account the particular challenges of part-time students and that our aim was to be able to support them by presenting the material of the course in an accessible way and also by helping them to develop the necessary non-cognitive skills that they needed to do well academically.

Some students however showed scepticism about the usefulness of focussing on skills development. This is exemplified by the following comment:

"Please make sure that at least $50 \%$ of the marks in the course come from content knowledge, the rest can come from skills. I believe skills are not taught but born with. So those other students who study hard deserve $50 \%$ pass mark. But I will do my best to achieve more skills."

This student understood that the assessment of the non-cognitive skills was also going to became part of the course. It was clarified that the assessments making up the marks for the course would be as in previous years, but that what we were hoping to achieve was to blend the teaching of content knowledge with the teaching of non-cognitive skills to support them in the mastering of the content knowledge. This comment was also very useful as it allowed us to have a discussion around the concepts of growth versus fixed mindsets. According to Dweck 
(2017) students with growth mindsets believe that their intelligence is not fixed and that they can always improve and acquire new skills. One of the main characteristics of growth mindset students is that they are not afraid of making mistakes as they use the mistakes as part of their learning process in order to continue improving. For these students failure means that they have not mastered the material "yet". Fixed mindset students, on the other hand, believe that they cannot improve beyond a certain point that is fixed by nature. From a learning perspective a fixed mindset can be very debilitating as it demotivates students and can potentially have a negative impact on their academic behaviour. We explained to the students that it has been shown scientifically that intelligence is not fixed and that we all have the capacity to grow and develop new skills. Precisely what we were hoping to achieve was to show them practical ways of acquiring those skills.

\section{Learning strategies}

Weeks two and three in the course focussed on learning strategies. Rather than taking the conventional approach of lecturing from slides and requiring students to work through questions after class, we decided to show the students how we approached preparing for the content of the lectures and revising the topics that were going to be covered. The key focus of these lectures was on active reading and on the preparation of summaries for each topic. From the initial questionnaire we knew that students did not do any pre-reading before lectures and that most of them did not feel confident preparing summaries.

We encouraged students to read aloud some sections of the textbook and to make connections to prior learning. We also encouraged students to make notes as they were reading, identifying terms they were not familiar with and looking for the definitions of those terms. Having covered the theory we then applied the principles to answering a particular question, making explicit the link between the theory and its application in the question that they were tackling. We also demonstrated how to do summaries after a particular topic was covered. From week three onwards after each section was completed we provided time for the students to complete their own summaries. The lecturer would also do a summary on the board as the students worked on their personal summaries. It was encouraging to see that students took this task seriously and that they also started to interact with each other as they added to their individual summaries.

\section{Prior knowledge and academic perseverance}

The topics covered in weeks four and five are topics that build on second year knowledge. Traditionally these are also topics that students find hard. In week four we covered the material 
for the process costing lecture in a similar way as we had done in the previous weeks and also encouraged the students to do the summary for the section. We then asked them to work through a question. We soon noticed that the majority of the students were not able to make progress and that they had stopped attempting to answer. At this point we explained to them the importance of perseverance and we also showed them how the question could have been answered from the information that they already had in their summaries.

During our reflection after the lecture we realised that even though the approach that we had taken had worked for the topics of the previous weeks, for a topic that built on second year knowledge it was too much to expect students to be able to revise prior work and cover new material in the same session. The conclusion that we came to is that for this topic we had to guide students to revise the second year content before coming to class. At this point we thought that if we were willing to sacrifice a morning during the weekend to reinforce their knowledge of the principles in this section, we would be in a position to not only support them academically, but also, through a show of goodwill, to gain their trust. Even though we were exhausted we decided to arrange an additional contact session for the next Saturday morning.

The majority of the students attended the lecture on Saturday. Students were clearly grateful to us for the time, energy and effort we afforded them in running the extra session. One student specifically mentioned that he had only come to the class because he knew we were giving up our Saturday to support them, and that he prepared well for the lecture because he did not want to disappoint us. He was not the only one to have embraced the added opportunity of learning with the vast majority of students demonstrating greater perseverance in attempting to solve problem questions by themselves or in small groups. After that Saturday session, students were clearly more motivated, with some even asking how they could better prepare for the next lecture on standard costing. We therefore gave them some homework to do. We also emphasised to them that it was extremely important to revise their second year work prior to the lecture.

Even though students left motivated and eager to go and prepare for the next lecture, we were disappointed to see that only a few students had actually done the homework that we had suggested. We took this opportunity to further explore with them the challenges that they face as part-time students to prepare for lectures and to find time for studying. This experience also made us realise that behavioural change requires time and that there is a limit of how much we could do as lecturers to help students take responsibility for their learning outside the classroom. We remained committed to focussing on what we could influence directly, which was to create a positive learning environment and to continue to introduce them to the key aspects of the Non-Cognitive Skills Five Factor Model. 


\section{Test preparation}

In the final session of the first teaching cycle, the last one before the test, we had a session on stress management and examination technique. The aim was to link students' personality styles to how they deal with anxiety, stress and problem solving before and during tests (Caprara et al. 2011; Dweck, Walton and Cohen 2011). Even though some students were initially resistant to the ideas presented, the majority of the students actively engaged with the material. Different personality styles, along with motivational drivers and coping strategies were analysed and discussed. In response to the session one student commented:

"This session made me think a lot about my approach to studying and where I may be holding myself back."

During the session our attention was drawn to the input of a student who was attending the class for the first time. Her comments were very negative. She felt that tests were "always" unfair and as a result of that she was very angry with the lecturers. The rest of the class however did not share her views. At this point we realised that the class had moved on from their initial perception of the role of the lecturers in the course and that changes in attitudinal and behavioural patterns had started to occur.

\section{Second questionnaire and group feedback session}

After the test students completed an additional questionnaire in which we asked them about their performance in the test and we also held a group feedback session. It was pleasing to see that in the feedback provided none of the students complained that the test was unfair or too hard. Some of their comments were as follows:

"I felt it was a fair paper."

"I felt good because I thought I wrote very well, even though I didn't finish the test. At least I answered most of the questions."

"I felt horrible because I knew I should have passed but I did not finish."

As lecturers we were particularly encouraged by the change in attitude of the students after their test. Students were displaying higher levels of academic perseverance, even if they didn't perform as well as they had hoped and some specifically commented on their improved learning strategies:

"My learning technique in terms of this course is way better than before and I am not afraid to 
tackle the difficult questions."

"I feel like I have to go back and learn/practice more questions; I need to dedicate at least two hours a day to the subject. I feel like I could have done much better than the mark I received."

The feedback that we received gave us the confidence and energy to undertake the next teaching cycle, knowing that we were making a difference in the attitudinal and behavioural patterns of the students.

\section{EVALUATION OF THE SECOND TEACHING CYCLE}

From the feedback obtained from the students and our own self-reflection on the challenges that we had encountered in the first teaching cycle we decided to structure the second teaching cycle around the following non-cognitive skills: exam technique, time management, the development of metacognition, fostering growth mindsets and group work. Table 2 contains the plan of action that was implemented.

Table 2: Second teaching cycle

\begin{tabular}{|c|l|l|l|}
\hline Week & Lecture topic & \multicolumn{1}{|c|}{ Skills addressed } & \multicolumn{1}{|c|}{ Implementation plan } \\
\hline 7 & $\begin{array}{l}\text { Activity Based } \\
\text { Costing }\end{array}$ & $\begin{array}{l}\text { Academic Behaviours } \\
\text { Examination techniques }\end{array}$ & $\begin{array}{l}\text { Explain how to review a test or exam and } \\
\text { how to learn from the mistakes made. }\end{array}$ \\
\hline 8 & Decision Making & $\begin{array}{l}\text { Learning Strategies } \\
\text { Creating realistic timetables }\end{array}$ & $\begin{array}{l}\text { Help prepare timetables for the rest of the } \\
\text { academic year, with the focus on finding time } \\
\text { to prepare for the exams }\end{array}$ \\
\hline 9 & $\begin{array}{l}\text { Relevant } \\
\text { Costing }\end{array}$ & $\begin{array}{l}\text { Learning Strategies } \\
\text { Time management under } \\
\text { exam conditions }\end{array}$ & $\begin{array}{l}\text { Learn how to allocate time to each question } \\
\text { based on marks available and provide } \\
\text { students with strategies for dealing with } \\
\text { uncertainty }\end{array}$ \\
\hline 11 & $\begin{array}{l}\text { Constraints } \\
\text { Evaluation }\end{array}$ & $\begin{array}{l}\text { Learning Strategies } \\
\text { Metacognition }\end{array}$ & $\begin{array}{l}\text { Introduce the principle of metacognition as a } \\
\text { way to foster responsibility for one's own } \\
\text { learning }\end{array}$ \\
\hline 12 & $\begin{array}{l}\text { Academic Mindsets } \\
\text { My ability and competence } \\
\text { grow with my effort }\end{array}$ & $\begin{array}{l}\text { Discuss the progress that the students had } \\
\text { made and revisit the growth mindset } \\
\text { principles so as to motivate the students to } \\
\text { continue working }\end{array}$ \\
\hline Management & $\begin{array}{l}\text { Social Skills } \\
\text { Group work }\end{array}$ & $\begin{array}{l}\text { Divide the class into groups and get each } \\
\text { group to prepare and present a section of the } \\
\text { topic to the rest of the class }\end{array}$ \\
\hline
\end{tabular}

In the week following the test review we emphasised to the students the importance of putting in place a study plan that would cover the weeks remaining until their final exams. To assist with this, each student was given a calendar and asked to diarise up-coming important dates/commitments, such as work trips and family commitments, as well as the exam dates for all their subjects. This exercise made the students realise how close the final examinations actually were.

Throughout this cycle we continued to spend time focusing on time management and exam technique. We also showed students the benefit of time-management with regard to question completion. Students needed to understand that when they spent too much time on a specific 
question they were sacrificing marks in the questions that followed. While working through questions, we illustrated how students could save time by planning and structuring their answers in a logical way and displayed the time management skills that were necessary to complete questions under exam conditions. We also used the last lectures of the course to introduce students to the principles of metacognition and to reinforce the importance of having growth mindsets. Metacognition comprises the thinking processes that allow students to reflect and to be aware of their level of mastery of a topic, as well as their ability to monitor their own learning (Zimmerman 2008). Students who are able to think and reflect on their way of thinking and mastery of topics are better able to direct their efforts to achieve the academic goals that they set for themselves.

\section{Students' evaluation of the intervention}

At the end of the final lecture we asked students to complete a final questionnaire so that we could evaluate the overall impact of the intervention. In total, twenty seven students completed the questionnaire. Out of these students, twenty six said that they found the course enjoyable, and twenty three of them indicated that they had changed their study approach as a result of the intervention. The following responses exemplify students' perceived changes in attitudinal and behavioural patterns:

\footnotetext{
"My approach to studying is now more focused on maximizing the productivity I get from the minimal hours I have to study as a part-time student and I try to do this by using a similar approach to the one used in class."

"I am now studying ahead of time and doing tutorials without looking at the solutions."

"The way the lecture examples were tackled helped me with a technique to tackle tutorial questions and I intend to use it to tackle the exam."

"I have used the basic principles the lecturers taught in order to have the confidence to approach even the longest exam question."

"I now redo the questions under exam conditions."

"I learnt to prepare my own study notes after lectures."
}

Twenty six students said they had changed the way they planned their time. In addition to highlighting the benefits of proper time management, a number of students also indicated that the group work was especially beneficial:

"I have definitely benefited from group work. It's much better to explain a topic to someone else and discuss it with them than having to do it alone."

"Group work, as there is space to reflect on your own approach and why it is possibly failing."

The majority of students also indicated that they spent more time practicing questions and that 
they prioritised their studies better. Some of the final thoughts from the students with regard to the course were as follows:

"Teaching style, giving exam technique during lectures, doing tuts as a group as well as having passionate lecturers, should all continue."

"Continue bringing challenging exams and making the class interactive, but importantly being approachable."

"Good to work through tutorials in class as we part-time students do not usually have this benefit."

"My lecturers helped me overcome my fear of ManAcc and made me realise I can pass it. I have the knowledge, I just need to stay calm and work."

\section{REFLECTIONS AND LEARNINGS FROM THE INTERVENTION}

In terms of the academic performance of the students the pass rate for the year was 42 per cent. This was an improvement from the previous year in which the pass rate for the course was only 27 per cent. The pass rate for the repeat students was 46 per cent. This pass rate was much higher than the 8 per cent pass rate for repeat students in 2015. Despite the fact that the pass rate was not as high as we would have liked, the results of the intervention suggest that it is possible to help students develop non-cognitive skills through a structured approach that combines the teaching of content knowledge with the development of skills.

Initially we were faced with a class that had a very negative attitude towards the course and towards previous lecturers. Gaining the trust of the students by acknowledging their concerns and explaining the overall aim of the intervention was very important. Students reacted positively to our attempts to support them holistically, but we must admit that sometimes we felt that students' adoption of new behaviours and skills was too slow. Learning to manage our expectations while continuing to encourage the students to grow and develop was one of the main insights that we obtained from the intervention.

We also think that having a consistent approach to all the lectures was important. As the course progressed, students started to look forward to our explanations and insights on the role of non-cognitive skills. Also being able to practice in class under the guidance of the lecturers was very beneficial for the students. This intervention went beyond merely making students aware of non-cognitive skills. We tried to show students how to acquire the skills and gave them the time to practice and to revise their approach over time. Without this continuous focus on practice we may not have obtained the results that we did. Finally, the importance of group work cannot be emphasised enough. Students were able to build relationships with their peers and soon they started supporting each other as they grappled with content knowledge and with the acquisition of new skills.

While this intervention focussed on a part-time class with very specific challenges, we 
believe that it is possible to introduce large number of students doing full-time courses to the same range of non-cognitive skills. For this to happen lecturers need to be open to introducing changes to the way they structure their courses. Given the current challenges facing the universities in South Africa this type of approach could potentially improve the academic outcomes of students and better prepare them to face with confidence the challenges that they will face as they enter the workforce.

\section{REFERENCES}

Allensworth, E. and J. Q. Easton. 2007. What matters for staying on-track and graduating in Chicago Puplic Schools. Chicago: University of Chicago Consortium on Chicago School Research.

Aronson, J., G. L. Cohen and W. McColskey. 2009. Reducing stereotype threat in classrooms: A review of social-psychological intervention studies on improving the achievement of black students. Issues \& Answers. REL 2009-076. Regional Educational Laboratory Southeast.

Bandura, A. 1986. Social foundations of thought and action: a social cognitive theory. Englewood Cliffs: Prentice Hall.

Bandura, A. 1997. Self-efficacy: The exercise of control. New York: Freeman.

Bandura, A. 2011. "Cultivate self-efficacy for personal and organizational effectiveness." In Handbook of principles of organizational behavior: Indispensable knowledge for evidence-based management., ed. Edwin Locke, 179-200. New Jersey: John Wiley \& Sons.

Bidjerano, T. and D. Yun Dai. 2007. The relationship between the big-five model of personality and self-regulated learning strategies. Learning and Individual Differences 17(1): 69-81. doi: https://doi.org/10.1016/j.lindif.2007.02.001

Blackwell, L. S., K. H. Trzesniewski and C. S. Dweck. 2007. Implicit theories of intelligence predict achievement across an adolescent transition: A longitudinal study and an intervention. Child Development 78(1): 246-263. doi: https://doi.org/10.1111/j.1467-8624.2007.00995.x

Caprara, G. V., M. Vecchione, G. Alessandri, M. Gerbino and C. Barabaranelli. 2011. The contribution of personality traits and self-efficacy beliefs to academic achievement: A longitudinal study. British Journal of Educational Psychology 81(1): 78-96. doi: https://doi.org/10.1348/20448279.002004

Cohen, G. L. and J. Garcia. 2008. Identity, belonging and achievement: A model, intervention, implications. Current Directions in Psychological Science 17(6): 365-369. doi: https://doi.org/10.1111/j.1467-8721.2008.00607.x

Cooper, H., J. C. Robinson and E. A. Patall. 2006. Does homework improve academic achievement? A syhesis of research, 1987-2003. Review of Educational Research 76(1): 1-62. doi: https://doi.org/10.3102/00346543076001001

Cross, M. and C. Carpentier. 2009. New students in South African higher education: Institutional culture, student performance and the challenge of democratisation. Perspectives in Education 27(1): 6-18.

Cunningham, B. M. 2008. Using action research to improve learning and the classroom learning environment. Issues in Accounting Education 23(1): 1-30. doi: https://doi.org/ 10.2308/iace.2008.23.1.1

Dembo, M. H. and H. Seli. 2013. Motivation and learning strategies for college success: A focus on self-regulated learning. New York: Routledge.

Dewey, J. 1958. Experience and education. New York: Macmillan.

Duckworth, A. L. and M. E. P. Seligman. 2005. Self-discipline outdoes IQ in predicting academic performance of adolescents. Psychological Science 16: 939-944. doi: https://doi.org/ 


\section{$10.1111 / \mathrm{j} .1467-9280.2005 .01641 . \mathrm{x}$}

Durlak, J. A., R. P. Weissberg, A. B. Dymnicki, R. D. Taylor and K. B. Schellinger. 2011. The impact of enhancing students' social and emotional learning: A meta-analysis of school-based universal interventions. Child Development 82(1): 405-432. doi: https://doi.org/10.1111/j.14678624.2010.01564.x

Dweck, C. S. 2017. Mindset-updated edition: Changing the way you think to fulfil your potential. London: Hachette UK.

Dweck, C. S., G. M. Walton and G. L. Cohen. 2011. Academic tenacity: Mindsets and skills that promote long-term learning. Seattle: Bill \& Melinda Gates Foundation.

Eccles, J. S., T. F. Acller, R. Futterman, S. B. Goff, C. M. Kaczala, J. L. Meece and C. Midgley. 1983. Expectancies, values and academic behaviors, achievement and achievement motivation. San Francisco: W.H. Freeman.

Farrington, C. A., E. Roderick, E. Allensworth, J. Nagaoka, T. S. Keyes, D. W. Johnson and N. O. Beechum. 2012. Teaching adolescents to become learners. The role of noncognitive factors in shaping school performance: A critical literature review. Chicago: University of Chicago Consortium on Chicago School Research.

Fereday, J. and E. Muir-Cochrane. 2006. Demonstrating rigor using thematic analysis: A hybrid approach of inductive and deductive coding and theme development. International Journal of Qualitative Methods 5(1): 80-92. doi: https://doi.org/10.1177/160940690600500107

Goodenow, C. 1993. Classroom belonging among early adolescent students relationships to motivation and achievement. The Journal of Early Adolescence 13(1): 21-43. doi: https://oi.org/ $10.1177 / 0272431693013001002$

Gynnild, Vidar, Anders Holstad and Dag Myrhaug. 2008. Identifying and promoting self regulated learning in higher education: roles and responsibilities of student tutors. Mentoring \& Tutoring: Partnership in Learning 16(2): 147-161.

Harvey, O. J. and H. M. Schroder. 1963. Cognitive aspects of self and motivation. In Motivation and social interaction-cognitive determinants, ed. O. J. Harvey. New York: Ronald Press.

Hlalele, D. J. 2010. Do learning skills acquired in the university access programme enhance participation in academic practice? South African Journal of Higher Education 24(1): 98-110.

Karabenick, S. A. and M. H. Dembo. 2011. Understanding and facilitating self-regulated help seeking. New Directions for Teaching and Learning 2011(126): 33-43. doi: https://doi.org/10.1002/tl.442

Kasworm, C. E. 2008. Emotional challenges of adult learners in higher education. New Directions for Adult and Continuing Education 120(Winter 2008): 27-34. doi: https://doi.org/10.1002/ace.313

Kember, D. 1999. Integrating part-time study with family, work and social obligations. Studies in Higher Education 24(1): 109-124. doi: https://doi.org/10.1080/03075079912331380178

Malecki, C. K. and S. N. Elliot. 2002. Children's social behaviors as predictors of academic achievement: A longitudinal analysis. School Psychology Quarterly 17(1): 1-23. doi: https://doi.org/10.1521/scpq.17.1.1.19902

McNiff, J. and J. Whitehead. 2009. Doing and writing action research. London: Sage.

Menter, Ian, Dely Elliot, Moira Hulme, Jon Lewin and Kevin Lowden. 2011. A guide to practitioner research in education. London: SAGE.

Merino, A., S. Jooste and K. Vermeulen. 2017. "An alternative journey towards flipping the classroom through self-regulated learning skills.” Biennial International Conference, Drakensberg, South Africa.

Nagaoka, J., C. A. Farrington, M. Roderick, E. Allensworth, T. S. Keyes, D. W. Johnson and N. O. Beechum. 2013. Readiness for college: The role of noncognitive factors and context. Voices in Urban Education 38: 45-52.

Oyserman, D., D. Bybee and K. Terry. 2006. Possible selves and academic outcomes: How and when possible selves impel action. Journal of Personality and Social Psychology 91: 188-204. doi: 
https://doi.org/10.1037/0022-3514.91.1.188

Paris, S. G. and P. Winograd. 1990. How metagognition can promote academic learning and instruction: Dimentions of thinking and cognitive instruction. Hillsdale: NJ: Lawrence Erlbaum Associates.

Pintrich, P. R. 2004. A conceptual framework for assessing motivation and self-regulated learning in college students. Educational Psychology Review 16(4): 385-407. doi: https://doi.org/ 10.1007/s10648-004-0006-X

Pintrich, P. R. and E. V. De Groot. 1990. Motivational and self-regulated learning components of classroom academic performance. Journal of Educational Psychology 82(1): 33-40. doi: https://doi.org/10.1037/0022-0663.82.1.33

Pym, J. and R. Kapp. 2013. Harnessing agency: Towards a learning model for undergraduate students. Studies in Higher Education 38(2): 272-284. doi: https://doi.org/10.1080/03075079.2011.582096

Radovon, M. 2011. The relation between distance students' motivation and their use of learning strategies and academic success. The Turkish Online Journal of Educational Technology 10(1): 216-222.

Schreiber, B. and D. Yu. 2016. Exploring student engagement practices at a South African university: Student engagement as reliable predictor of academic performance. South African Journal of Higher Education 30(5): 157-175. doi: https://doi.org/10.20853/30-5-593

Silén, C. and L. Uhlin. 2008. Self-directed learning - a learning issue for students and faculty! Teaching in Higher Education 13(4): 461-475. doi: https://doi.org/10.1080/13562510802169756

Steenkamp, L., R. Baard and B. Frick. 2012. A holistic investigation into a tutor programme in firstyear Financial Accounting. Meditari Accountancy Research 20(1): 68-87. doi: https://doi.org/ $10.1108 / 10222521211234237$

Tishman, S. and E. Jay. 1993. Teaching thinking dispositions: From transmission to enculturation. Theory Into Practice 32(3): 147-153. doi: https://doi.org/10.1080/00405849309543590

Urban, B. and P. Richard. 2015. Perseverance among university students as an indicator of entrepreneurial intent. South African Journal of Higher Education 29(5): 263-278.

Vygotsky, L. S. 1978. Mind in society: The development of higher psychological processes. Cambridge, MA: Harvard University Press.

Wilmot, L. and A. Merino. 2015. A personal reflection of the impact of adopting a student-centred teaching approach to influence accounting students' approaches to learning. South African Journal of Higher Education 29(6): 257-274.

Won, S., C. A. Wolters and S. A. Mueller. 2017. Sense of belonging and self-regulated learning: Testing achievement goals as mediators. The Journal of Experimental Education: 1-17.

Yeager, D. S. and G. M. Walton. 2011. Social-psychological interventions in education: They're not magic. Review of Educational Research 81(2): 267-301. doi: https://doi.org/ 10.3102/0034654311405999

Zimmerman, B. J. 2002. Becoming a self-regulated learner: An overview. Theory Into Practice 41(2): 64-70. doi: https://doi.org/10.1207/s15430421tip4102 2

Zimmerman, B. J. 2008. Investigating self-regulation and motivation: Historical background, methodological developments, and future prospects. American Educational Research Journal 45(1): 166-183. doi: https://doi.org/10.3102/0002831207312909

Zimmerman, B. J., A. Bandura and M. Martinez-Pons. 1992. Self-motivation for academic attainment: The role of self-efficacy beliefs and personal goal setting. American Educational Research Journal 29(3): 663-676. doi: https://doi.org/10.3102/00028312029003663.

Zimmerman, B. J. and R. Risemberg. 1997. Becoming a self-regulated writer: A social cognitive perspective. Contemporary Educational Psychology 22(1): 73-101. doi: https://doi.org/10. 1006/ceps.1997.0919 